\title{
Pengaruh Merokok Terhadap Perubahan Akut Tekanan Darah
}

\author{
Muhammad Iskandar', Yose Ramda Ilhami', Gusti Revilla ${ }^{3}$ \\ ${ }^{1}$ Fakultas Kedokteran Universitas Andalas, Padang \\ ${ }^{2}$ Bagian Fisiologi, Fakultas Kedokteran Universitas Andalas, Padang \\ ${ }^{3}$ Bagian Anatomi, Fakultas Kedokteran Universitas Andalas, Padang
}

\begin{abstract}
A B S T R A C T
Latar Belakang. Rokok mengandung bermacam-macam zat kimia yang sebagian besar dari zat tersebut adalah zat beracun. Beberapa diantaranya adalah nikotin dan $\mathrm{CO}$, Nikotin dan $\mathrm{CO}$ mampu memengaruhi berbagai aktivitas didalam tubuh seperti aktivitas saraf simpatis, memengaruhi jumlah Nitrit Oksida, hingga bersaing dengan Oksigen dalam berpasangan dengan Haemoglobin didalam tubuh. Penelitian ini bertujuan untuk mengetahui pengaruh dari merokok terhadap perubahan akut tekanan darah seseorang.
\end{abstract}

Objektif. Mengetahui perbedaan tekanan darah sebelum dan setelah merokok.

Metode. Penelitian ini merupakan penelitian eksperimental dengan desain one group pre test-post test. Sampel pada penelitian ini adalah mahasiswa laki-laki jurusan teknik mesin Universitas Andalas yang sudah merupakan perokok aktif sejak sebelum penelitian ini dilakukan. Pengambilan sampel dilakukan dengan metode consecutive sampling, dan didapatkan jumlah sampel sebanyak 25 orang. Analisis data dilakukan menggunakan analisis univariat untuk mengetahui karakteristik sampel dan analisis bivariat dilakukan dengan tujuan untuk mengetahui ada atau tidaknya pengaruh akut dari merokok terhadap tekanan darah. Analisis bivariat dilakukan menggunakan Paired Sample T Test dan Wilcoxon Signed Rank Test. Hasil analisis bivariat ini dikatakan bermakna jika nilai $p$ yang diperoleh $<0,05$.

Hasil. Hasil dari penelitian ini didapatkan perbedaan yang bermakna pada tekanan darah sebelum merokok dengan tekanan darah setelah merokok, ini ditunjukkan oleh perolehan nilai $p$ yang <0,05 yaitu sebesar 0,001 pada tekanan darah sistolik dan 0,040 pada tekanan darah diastolik.

Kesimpulan. Terdapatnya pengaruh dari merokok terhadap perubahan akut tekanan darah.

Kata kunci: merokok, tekanan darah

Background. Cigarettes contain a variety of chemicals, most of which are toxic substances. Some of them are nicotine and $\mathrm{CO}$, Nicotine and $\mathrm{CO}$ can influence various activities in the body such as sympathetic nerve activity, affect the amount of Nitric Oxide, to compete with Oxygen in pairing with Hemoglobin in the body.

Objective. This study aims to determine the effect of smoking on acute changes in a person's blood pressure.

\begin{abstract}
Method. This research is an experimental study with one group pre-post-test design. The sample in this study were male students majoring in mechanical engineering at Andalas University who had been active smokers since before the study was conducted. Sampling was done by consecutive sampling method and obtained a total sample of 25 people. Data analysis was performed using the univariate analysis to determine sample characteristics and bivariate analysis was carried out to find out whether or not there was an acute effect of smoking on blood pressure. Bivariate analysis was performed using the Paired Sample T-Test and Wilcoxon Signed Rank Test. The results of this bivariate analysis are said to be meaningful if the $p$-value obtained $<0.05$.
\end{abstract}

Result. The results of this study found a significant difference in blood pressure before smoking with blood pressure after smoking, this is indicated by the acquisition of $p$-value $<0.05$ which is equal to 0.001 for systolic blood pressure and 0.040 for diastolic blood pressure.

Conclusion. There is an effect of smoking on acute changes in blood pressure.

Keywords: Cigarettes, Smoking, Blood Pressure

\section{Apa yang sudah dilketahui tentang topik ini?}

Merokok dapat memengaruhi tekanan darah seseorang, hal ini dikarenakan berbagai macam zat kimia yang terdapat dalam rokok.

\section{Apa yang ditambahkan pada studi ini?}

Perbedaan rata-rata tekanan darah sebelum dan setelah merokok didapatkan kenaikan sebesar $2.32 \mathrm{mmHg}$ untuk tekanan darah sistolik dan $2.2 \mathrm{mmHg}$ untuk tekanan darah diastolik.

\section{CORRESPONDING AUTHOR}

Name: Muhammad Iskandar

Phone: +62 82387209973

E-mail: nanda.iskandarr12@gmail.com

\section{ARTICLE INFORMATION}

Received: September $23^{\text {rd }}$, 2020

Revised: October $15^{\text {th }}, 2020$

Available online: October $31^{\text {st }}, 2020$ 


\section{Pendahuluan}

Terjadi kurang lebih 6 juta kematian di dunia tiap tahunnya karena tembakau dan diperkirakan akan terus meningkat menjadi diatas 8 juta pada tahun 2030.1 World Health Organization (WHO) menyatakan bahwa merokok merupakan faktor kedua terbanyak yang menyebabkan kematian dini. Merokok diperkirakan menyebabkan 1,6 juta kematian tiap tahun di benua Eropa. ${ }^{2}$ WHO juga menyampaikan $80 \%$ dari jumlah kematian tersebut terjadi di negara negara dengan pendapatan perkapita rendah hingga sedang. ${ }^{3}$ Salah satunya di Indonesia, merokok diperkirakan membunuh 200.000 orang tiap tahunnya dan lebih dari 97 juta orang yang bukan perokok secara terus menerus menjadi perokok pasif (second hand smoke) yang sering terpapar asap rokok di tempat umum ataupun di rumah. ${ }^{3}$

Menghisap sebatang rokok mempunyai pengaruh terhadap kenaikan tekanan darah, ini dikarenakan zat yang terkandung dalam rokok diperkirakan berjumlah 4000 macam dan 200 jenis diantaranya adalah zat beracun. ${ }^{4}$ Satu dari sekian banyak zat tersebut adalah nikotin. Nikotin mampu menurunkan produksi Nitrit Oksida yang akan menyebabkan terganggunya sensitivitas dari barorefleks. Selain itu nikotin juga menyebabkan peningkatan aktivitas sistem saraf simpatis karena adanya serabut aferen yang sangat sensitif terhadap rangsangan nikotin. Ketika sistem saraf simpatis bekerja, otak akan menerima sinyal untuk melepas barorefleks yang bertugas untuk menghambat kenaikan tekanan darah tapi saat barorefleks tidak mampu untuk mengimbangi, maka tekanan darah akan terus naik. Aktivitas sistem saraf simpatis ini akan mencapai puncak 5 - 10 menit setelah terpapar nikotin. ${ }^{5}$

Pada rokok juga terdapat partikel organik. Partikel organik ini dapat menaikkan tekanan darah seseorang ketika terjadi pembakaran zat organik (daun tembakau) yang kondisinya mirip dengan polusi udara (pembakaran bahan bakar fossil). Ini akan menyebabkan penurunan produksi NO dan respon inflamasi yang juga mengganggu keseimbangan sistem saraf otonom dan mengakibatkan hiperaktivitas sistem saraf simpatik. ${ }^{5}$ Beberapa kepustakaan mengatakan merokok dapat menyebabkan kenaikan $4 \mathrm{mmHg}$ pada tekanan sistolik seseorang. ${ }^{6}$

Zat lain yang juga terdapat dalam rokok adalah CO atau karbon monoksida, zat ini 200 kali lebih cepat dalam mengikat $\mathrm{Hb}$ dibandingkan dengan 02. Kemampuan CO ini menyebabkan akumulasi HbCO lebih banyak dibandingkan $\mathrm{HbO} 2$ pada perokok yang efeknya akan semakin terasa ketika durasi seseorang terpapar CO didalam ruangan semakin lama. ${ }^{7}$ CO yang dihasilkan asap rokok bisa menyebabkan kram pada pembuluh darah, sehingga tekanan darah naik, bahkan dapat mengakibatkan robeknya pembuluh darah. ${ }^{4}$

Tekanan darah dan rokok sebenarnya adalah dua hal yang sudah sangat sering dibicarakan, tapi masih sangat sedikit yang memaparkan hubungan waktu antara kedua faktor tersebut. ${ }^{8}$ Alasan ini merupakan salah satu alasan penulis untuk melakukan penelitian ini. Selain itu, angka pertumbuhan perokok usia muda di Indonesia juga terus mengalami kenaikan tiap tahunnya. Data dari Riskesdas menyampaikan bahwa terjadi peningkatan sebesar 20\% dari tahun 2007 sampai tahun 2013.1 Salah satu penyebab meningkatnya prevalensi perokok usia muda ini adalah kurangnya pemahaman mereka tentang bahaya merokok dan banyaknya mitos mitos tentang rokok. $^{3}$

Alasan lain yang bisa membuat seseorang merokok adalah stress dan cemas. ${ }^{9}$ Stress dan cemas saat ini tidak hanya dirasakan oleh orang dewasa, keadaan ini juga sering dirasakan oleh mahasiswa yang sedang menjalani kuliahnya, apalagi dengan tuntutan dari sisi akademik dan non-akademik. Mulai dari kesulitan dalam menyelesaikan tugas, prestasi belajar yang menurun, tuntutan orang tua agar segera menyelesaikan studi, hingga hubungan sosial seperti menyesuaikan diri dengan teman sesama mahasiswa dengan karakteristik yang berbeda beda. ${ }^{9}$ Hal ini bisa menyebabkan beberapa orang menjadi perokok dan ketergantungan dengan rokok karena memercayai bahwa rokok memiliki fungsi sebagai penenang saat merasa stress dan cemas. $^{9}$ Hal ini bisa dihubungkan dengan mahasiswa teknik yang memiliki kegiatan perkuliahan yang padat, mulai dari kelas tatap muka, tugas praktikum, asistensi, hingga kegiatan ekstrakulikuler dalam ataupun luar kampus.

Penelitian yang juga dilakukan pada mahasiswa di Purwokerto mendapatkan hasil bahwa seluruh mahasiswa yang diteliti mengetahui dan memahami bahaya dari merokok. Terutama dengan adanya peringatan di kemasan rokok yang mengarahkan seseorang untuk tidak 
merokok, tetapi mahasiswa menyangkal peringatan tersebut dengan melihat kondisinya saat ini yang tidak menderita penyakit apapun. Bahkan ada yang menyimpulkan bahwa peringatan pada kemasan rokok hanya rekayasa yang dibuat untuk menakut-nakuti para perokok. ${ }^{10}$ Kejadian ini tidak jauh berbeda dengan kondisi di Jurusan Teknik Mesin Universitas Andalas, dari survey awal yang dilakukan pada mahasiswa teknik mesin didapatkan 16 dari 20 orang mahasiswa laki laki adalah perokok. Mereka rata rata sudah mengetahui bahaya merokok dari peringatan yang tercantum di kemasan rokok. Mereka teteap merokok dengan alasan membuat diri merasa tenang, hanya selingan, sebagai peningkat fokus saat mengerjakan tugas atau hanya ikut teman karena lingkungan sekitarnya rata rata adalah perokok. Hal ini membuat peneliti ingin melakukan penelitian tentang efek akut merokok terhadap tekanan darah pada mahasiswa teknik mesin dengan harapan setelah mengikuti penelitian ini dapat sama sama memahami bahwa merokok benar benar merusak tubuh yang efeknya dapat dilihat bukan hanya dalam jangka panjang tapi juga beberapa saat setelah seseorang merokok. Berdasarkan latar belakang tersebut peneliti tertarik untuk meneliti perbandingan tekanan darah pada mahasiswa teknik mesin Universitas Andalas sebelum dan setelah menghabiskan sebatang rokok.

\section{Metode}

Penelitian ini merupakan penelitian eksperimen dengan desain one-group pretestpostest design. Populasi dalam penelitian ini adalah mahasiswa laki laki jurusan teknik mesin Universitas Andalas dan sudah merupakan perokok aktif sebelum mengikuti penelitian ini. Sampel dipilih dari populasi yang memenuhi kriteria inklusi dan ekslusi. Kriteria Inklusi yang dipakai adalah mahasiswa laki laki jurusan teknik mesin Universitas Andalas yang sudah merupakan perokok aktif sebelumnya, bersedia menandatangani surat pernyataan persetujuan sebagai syarat persetujuan mengikuti penelitian ini, tidak baru melakukan aktivitas fisik yang berat. Kriteria Eksklusi yang digunakan adalah memiliki riwayat penyakit jantung berupa kelainan jantung bawaan, kelainan katup, dan infark miokard, memiliki riwayat hipertensi, mengonsumsi obat antihipertensi, dan sudah mengonsumsi rokok dalam 120 menit sebelum penelitian dilaksanakan

Besar sampel dihitung dengan rumus :

$$
\begin{aligned}
n & =\left[\frac{\left(Z_{\alpha}+Z_{\beta}\right) S}{X 1-X 2}\right]^{2} \\
& =\left[\frac{(1,64+1,28) 10}{5,88}\right]^{2}=24,661
\end{aligned}
$$

Keterangan:

$\mathrm{n}$ = Jumlah sampel minimal

$Z_{\alpha}=$ Deviat baku alfa, nilai batas normal dari tabel distribusi z yang besarnya tergantung pada nilai $\alpha$, untuk $\alpha=5 \%$; maka $Z_{\alpha}=1,64$

$Z_{\beta}=$ Deviat baku beta, nilai batas normal dari tabel distribusi z yang besarnya tergantung pada nilai $\beta$, untuk $\beta=10 \%$; maka $Z_{\beta}=1,28$

$S=$ Simpang baku dari selisih nilai antar kelompok, $\mathrm{S}=10$

$X 1-X 2=$ selisih minimal rerata yang dianggap bermakna.118,63 - 112,75 = 5,8

Berdasarkan pada perhitungan diatas, didapatkan besar sampel sebesar 24,661 sampel dan dibulatkan menjadi 25 sampel.

Teknik pengambilan sampel pada penelitian ini dipilih dengan teknik consecutive sampling dan untuk teknik analisi data yang digunakan adalah analisis univariat dan data diuji dengan Paired Sample t-test untuk mengetahui adanya hubungan yang bermakna atau tidak.

Hasil

Responden dari penelitian ini adalah mahasiswa laki laki perokok jurusan teknik mesin yang berada pada rentang usia 19 sampai 25 tahun. Dengan rata rata usia adalah $21,52 \pm 1,8$ tahun.

Tabel 1. Distribusi Responden Berdasarkan Indeks Brinkman

\begin{tabular}{ccc}
\hline Indeks Brinkman & Frekuensi (n) & Persentase (\%) \\
\hline Perokok Ringan & 24 & 96 \\
Perokok Sedang & 1 & 4 \\
\hline
\end{tabular}


Berdasarkan Tabel Indeks Brinkman diatas menunjukkan bahwa tingkat keparahan merokok didominasi oleh perokok ringan yaitu sebanyak 96\% dan 4\% lainnya adalah perokok sedang dan tidak ditemukan yang tergolong pada perokok berat.

Tabel 2. Tabel Deskripsi Tekanan Darah Sebelum dan Setelah Merokok

\begin{tabular}{lcc}
\hline Tekanan Darah & Sebelum Merokok & Setelah Merokok \\
\hline Sistolik & $122,12 \pm 5,12$ & $124,44 \pm 5,62$ \\
Diastolik & $77,68 \pm 4,94$ & $79,88 \pm 6,3$ \\
\hline
\end{tabular}

Tabel diatas menunjukkan rerata tekanan darah sebelum merokok adalah 122,12/77,68 mmHg dengan standar deviasi untuk tekanan darah sistolik sebesar 5,118 dan diastolik sebesar 4,939 dan untuk rerata tekanan darah setelah merokok adalah 124,44/79,88 mmHg dengan standar deviasi untuk tekanan darah sistolik sebesar 5,620 dan tekanan darah diastolik sebesar 6,30. Antara subjek dengan indeks brinkman ringan dan sedang tidak ditemukan perbedaan tekanan darah sebelum dan setelah merokok yang signifikan

Tabel 3. Hasil Pemeriksaan Tekanan Darah Sebelum dan Setelah Merokok

\begin{tabular}{llllll}
\hline \multirow{2}{*}{$\begin{array}{l}\text { Tekanan } \\
\text { Darah }\end{array}$} & \multicolumn{2}{c}{$\begin{array}{c}\text { Sebelum } \\
\text { Merokok }\end{array}$} & \multicolumn{2}{c}{ Setelah } & \multirow{2}{*}{ Asymp Sig } \\
\cline { 2 - 5 } & Mean & SD & Mean & SD & (2-tailed) \\
\hline Sistolik & 122,12 & 5,12 & 124,44 & 5,62 & 0,001 \\
Diastolik & 77,68 & 4,94 & 79,88 & 6,30 & 0,040 \\
\hline
\end{tabular}

Hasil pengukuran tekanan darah sebelum dan setelah merokok pada 25 orang sampel ini mendapatkan hasil tekanan darah sistolik yang meningkat pada 15 orang sampel, turun pada 3 orang sampel dan tidak berubah pada 7 orang sampel. Hasil pengukuran untuk tekanan darah diastolik didapatkan meningkat pada 12 orang sampel, turun pada 4 orang sampel, dan tidak berubah pada 9 orang sampel.

Rerata tekanan darah sistolik sebelum merokok pada sampel adalah 122,12. Rerata tekanan darah sistolik setelah merokok pada sampel adalah 124,44. Terlihat perbedaan antara rerata tekanan darah sistolik sebelum dan sesudah merokok adalah 2,32. Hasil uji statistik Paired Sample T test menunjukkan hasil Asymp sig (2-tailed) $=0,001(<0,05)$, yang berarti hipotesis didukung, maka dapat disimpulkan terdapat perbedaan yang bermakna antara tekanan darah sistolik sebelum dan setelah merokok.

Rerata tekanan darah diastolik sebelum merokok pada sampel adalah 77,68. Rerata tekanan darah diastolik setelah merokok pada sampel adalah 79,88. Terlihat perbedaan antara rerata tekanan darah diastolik sebelum dan sesudah merokok adalah 2,2. Hasil uji statistik Wilcoxon signed rank test menunjukkan hasil Asymp sig (2-tailed) $=0,040(<0,05)$, yang berarti hipotesis didukung, maka dapat disimpulkan terdapat perbedaan yang bermakna antara tekanan darah diastolik sebelum dan setelah merokok.

\section{Pembahasan}

Hasil penelitian ini menunjukkan 96\% dari seluruh subjek penelitian yang merupakan mahasiswa perokok yang tergolong sebagai perokok ringan dalam indeks brinkman. Empat persen lainnya tergolong sebagai perokok sedang dan tidak ada yang tergolong kepada perokok berat. Hasil penelitian ini sejalan dengan penelitian yang juga membahas indeks brinkman mahasiswa perokok di UIN Syarif Hidayatullah pada tahun 2016 yang mendapatkan hasil yaitu didominasi oleh perokok ringan, yang mana $74 \%$ dari mahasiswa perokok tergolong ke perokok ringan-sedang dan hanya $26 \%$ yang tergolong sebagai perokok berat. ${ }^{11}$ Hasil pengukuran tekanan darah pada kelompok perokok ringan dan sedang tidak tampak perbedaan yang signifikan, kemungkinan karena jumlah perokok sedang yang hanya 1 orang juga mempersulit analisis perbandingan antara masing masing kelompok. Tekanan darah sebelum merokok didapatkan dalam angka yang berbeda, hal ini bisa terjadi karena faktor lain yang memengaruhi tekanan darah seperti kualitas tidur, ataupun konsumsi garam. ${ }^{12,13}$

Hasil uji statistik dengan Paired Sample T test untuk tekanan darah sistolik menunjukkan bahwa terdapat perbedaan yang signifikan / bermakna dari tekanan darah sistolik sebelum dan setelah merokok dengan nilai $\mathrm{p}=0,001(<0.05)$ serta Hasil uji statistik dengan Wilcoxon signed rank test untuk tekanan darah diastolik juga menunjukkan terdapat perbedaan yang bermakna pada tekanan darah diastolik sebelum dan setelah merokok dengan perolehan nilai $p=0,040(<0.05)$. 
Perbedan rata-rata tekanan darah sebelum dan setelah merokok didapatkan kenaikan sebesar $2.32 \mathrm{mmHg}$ untuk tekanan darah sistolik dan 2.2 mmHg untuk tekanan darah diastolik. Hal ini sejalan dengan penelitian yang dilakukan oleh Takuro Kubozono yang juga mendapatkan hasil penelitian kenaikan tekanan darah sistolik dan diastolic setelah menghabiskan 1 batang rokok. ${ }^{14}$ Penelitian serupa juga dilakukan oleh Moo-Yong Rhee dan kawan-kawan yang mendapatkan hasil serupa, penelitian tersebut dilakukan kepada subjek dengan tekanan darah normal dan subjek yang memiliki hipertensi. Peningkatan tekanan darah diastolik pada subjek hipertensi yang awalnya $97 \pm 2$ menjadi $102 \pm 2$ dan pada subjek dengan tekanan darah normal didapatkan peningkatan dari $75 \pm 1$ menjadi $79 \pm 1$. Pada keduanya didapatkan peningkatan tekanan darah tetapi efek tersebut bertahan lebih lama pada subjek dengan tensi normal daripada subjek yang sudah hipertensi. ${ }^{15}$ Penelitian oleh William $\mathrm{H}$ Cooke juga menunjukkan terjadinya peningkatan tekanan darah diastolik antara sebelum dan setelah paparan nikotin sebesar $4 \mathrm{mmHg}$ pada subjek yang awalnya bukan seorang perokok. ${ }^{16}$ Hasil penelitian ini juga sejalan dengan artikel yang ditulis oleh Middlekauff Holly $\mathrm{R}$ yang menyatakan bahwa secara akut nikotin menyebabkan pelepasan katekolamin lokal dari terminal saraf andrenergik yang mana pada manusia pemberian nikotin secara intravena ataupun paparan dari merokok menyebabkan peningkatan tekanan darah dan denyut jantung akut yang memuncak dalam 5 - 10 menit setelah paparan. ${ }^{5}$ Penelitian George Papathanasiou menyatakan bahwa nikotin memengaruhi aktivitas dari saraf simpatis, menyebabkan peningkatan sekresi katekolamin dari ujung saraf bebas saraf simpatis serta memicu pelepasan lokal epinefrin dan norepinefrin, Selain itu juga terjadi penurunan kapasitas biosintetik dari prostasiklin. Stimulasi sekresi dari katekolamin dikombinasi dengan penurunan prostasiklin ini menghasilkan peningkatan akut tekanan darah dan peningkatan denyut jantung. ${ }^{2}$ Pada penelitian lain ditemukan nikotin tidak hanya menstimulasi di sistem saraf simpatis, tapi juga di area sentral di batang otak. Respon dari tekanan darah terjadi sebelum kenaikan dari adrenalin dan noradrenalin yang mengindikasikan bahwa efek dari merokok terhadap tekanan darah juga dimediasi melalui efek langsung pada ganglia perifer dan neuromuscular junction. ${ }^{17}$ Tekanan darah dinaikkan oleh efek gabungan dari peningkatan curah jantung, terutama karena kenaikan denyut jantung, dan peningkatan total resistensi pembuluh darah perifer. ${ }^{17}$

\section{Simpulan}

Dari penelitian ini dapat disimpulkan bahwa mahasiswa perokok di jurusan teknik mesin Universitas Andalas terbanyak berada pada usia 20 tahun, dengan tingkat keparahan merokok terbanyak adalah perokok ringan. Rerata nilai tekanan darah sistolik dan diastolik sebelum dan setelah merokok berada dalam klasifikasi tekanan darah normal dan terdapat perbedaan yang bermakna dari tekanan darah sistolik dan diastolik pada waktu sebelum merokok dan setelah merokok.

\section{Ucapan Terima Kasih}

Terimakasih penulis ucapkan kepada semua instansi yang telah membantu penyelesaian penelitian ini.

\section{Daftar Pustaka}

1. Kemeterian Kesehatan RI. Situasi Umum Konsumsi Tembakau. Infodatin. 2018;12.

2. Papathanasiou G, Mamali A, Papafloratos S, Zerva E. Effects of smoking on cardiovascular function: The role of nicotine and carbon monoxide. Heal Sci J. 2014;8(2):272-88.

3. IAKMI. 4th Indonesian Conference on Tobacco or Health 2017. 4th Indones Conf Tob or Heal 2017 [Internet]. 2017; Available from: http://ictohtcscindonesia.com/wpcontent/uploads/2018/01/Proceeding-Book-4thICTOH.pdf

4. Tisa K AN. Hubungan Antara Kebiasaan Merokok Dengan Tekanan Darah Meningkat Karyawan LakiLaki Di Nasmoco Semarang. J Kesehat Masy Univ Diponegoro. 2012;1(2):241-50.

5. Middlekauff HR, Park J, Moheimani RS. Adverse effects of cigarette and noncigarette smoke exposure on the autonomic nervous system: Mechanisms and implications for cardiovascular risk. J Am Coll Cardiol [Internet]. 2014;64(16):1740-50. Available from: http://dx.doi.org/10.1016/j.jacc.2014.06.1201

6. Gita SYO, Delmi S, Lestari Y. Hubungan Merokok dengan Kejadian Hipertensi pada Laki- Laki Usia 3565 Tahun di Kota Padang. Jurnal Kesehatan Andalas. 2015;4(2):434-40.

7. Fitriana D, Oginawati K. Studi Paparan Gas Karbon Monoksida Dan Dampaknya Terhadap Pekerja Di Terminal Cicaheum Bandung. J Teh Lingkung. 2012;18(1):21-9.

8. Eguchi K, Kario K. Smoking and hypertension. Nippon rinsho Japanese J Clin Med. 2006;6(2):242-6. 
9. Bawuna N, Rottie J, Onibala F. Hubungan Antara Tingkat Stres Dengan Perilaku Merokok Pada Mahasiswa Fakultas Teknik Universitas Sam Ratulangi. J Keperawatan UNSRAT. 2017;5(2):8.

10. Asngad M. Persepsi Mahasiswa Terhadap Peringatan Bahaya Merokok Pada Setiap Kemasan Rokok. IAIN Purwokerto [Internet]. 2016;52.

11. Rhee MY, Na SH, Kim YK, Lee MM, Kim HY. Acute Effects of Cigarette Smoking on Arterial Stiffness and Blood Pressure in Male Smokers With Hypertension. Am J Hypertens. 2007;20(6):637-41.

12. Cooke WH, Pokhrel A, Dowling C, Fogt DL, Rickards CA. Acute inhalation of vaporized nicotine increases arterial pressure in young non-smokers: a pilot study. Clin Auton Res. 2015;25(4):267-70.

13. Kubozono T, Miyata M, Ueyama K, Hamasaki S, Kusano K, Kubozono O, et al. Acute and chronic effects of smoking on arterial stiffness. Circ J. 2011;75(3):698-702.

14. Suminar, Ichtiarsyah. Hubungan Kadar Salivary Calcium dengan Tingkat Keparahan Merokok Berdasarkan Indeks Brinkman pada Perokok dan Non Perokok (Skripsi).Jakarta:UIN Syarif Hidayatullah;2016

15. Lo K, Woo B, Wong M, Tam W. Subjective sleep quality, blood pressure, and hypertension: a meta analisis. J Clin Hypertens. 2018;20:592-605.

16. William B, Farquhar, David GE, Claudine TJ. Dietary Sodium and Health : More Than Just Blood Pressure. J Am Coll Cardiol. 2015 March 17; 65(10): 1042-1050.

17. Omvik Per. How Smoking affects blood pressure. Blood Pressure. 1996:5(2):71-77 Omvik Per. How Smoking affects blood pressure. Blood Pressure. 1996:5(2):71-77 